\title{
Hematological and biochemical parameters of premature kids of goats subjected to different dexamethasone protocols
}

\section{Luis Gustavo Narciso $^{1}$ (D) Jefferson Ferreira Alcindo ${ }^{2 *}$ (D) Fernanda Bovino $^{3}$ (iD Juliane Teramachi Trevizan ${ }^{4}$ (i) Dielson da Silva Vieira ${ }^{1}$ (i) Breno Fernando Martins de Almeida $^{5}$ (i) Anelise Maria Bosco ${ }^{1}$ (D) Francisco Leydson Formiga Feitosa ${ }^{1}$ (i)}

${ }^{1}$ Universidade Estadual Paulista (UNESP), Departamento de Clínica, Cirurgia e Reprodução Animal, Faculdade de Medicina Veterinária de Araçatuba (FMVA), Araçatuba, SP, Brasil.

${ }^{2}$ Universidade Federal de Juiz de Fora (UFJF), Departamento de Medicina Veterinária, Juiz de Fora, MG, Brasil. E-mail: jefferson.alcindo@yahoo.com.br. "Correspondence author.

${ }^{3}$ Fundação Educacional de Andradina, Andradina, SP, Brasil.

${ }^{4}$ Centro Universitário Rio Preto (UNIRP), Departamento de Reprodução Animal, São José do Rio Preto, SP, Brasil.

${ }^{5}$ Centro Universitário de Ourinhos (Unifio), Ourinhos, SP, Brasil.

ABSTRACT: Corticosteroid therapy has been used for ruminants to allow lung maturation and the birth of premature babies. However, when considering laboratory analyses of these animals, very little data is available regarding hematological and biochemical patterns, especially for premature goats, and the effects of corticotherapy on these parameters are unknown. In this context, the objective of this study was to evaluate the hematological and biochemical parameters during the first hours of life of premature kids from goats subjected to different dexamethasone protocols. For this, the goats were divided into four groups: group I, goats that received $20 \mathrm{mg}$ of dexamethasone at 139 days of gestation; group II, $2 \mathrm{mg}$ of dexamethasone from the 133rd to 136th day of gestation, $4 \mathrm{mg}$ from the 137th to 139th, and $20 \mathrm{mg}$ on the 140th; group III, $16 \mathrm{mg}$ of dexamethasone from the 139th day, with repeated doses every $12 \mathrm{~h}$ until elective surgery; and group IV, goats that received 4, 8, 16, and $20 \mathrm{mg}$ of dexamethasone at 137, 138, 139, and 140 days of gestation, respectively. Blood samples were obtained at birth (T0h) and after 1 (T1h), 12 (T12h), 24 (T24h), and $48 \mathrm{~h}(T 48 \mathrm{~h})$ of life for hemogram and serum biochemistry assessment of urea, creatinine, total protein (PT), and gamma-glutamyltransferase (GGT). PT levels and GGT activity were lower at birth in all groups and rose after colostrum ingestion. The creatinine values for all the experimental groups did not differ between TOh and TIh; however, they decreased in the subsequent moments. Except for group I, urea concentrations were higher at T48h than at TIh. The red blood cell, hemoglobin, hematocrit, and mean corpuscular hemoglobin counts decreased over time. The total leukocyte count behaved differently in different experimental groups, and was influenced by the levels of dexamethasone, mainly due to the change in the counts of segmented neutrophils and lymphocytes. It was concluded that significant changes in the hematological and biochemical parameters occur in the first hours of life of premature kids, and that the treatment of goats with dexamethasone can affect these parameters in a dose-dependent manner.

Key words: biochemistry, goats, corticotherapy, hematology, early parturition.

Parâmetros hematológicos e bioquímicos de cabritos prematuros de cabras submetidas a diferentes protocolos de dexametasona

RESUMO: A corticoterapia tem sido empregada em ruminantes com o objetivo de permitir a maturação pulmonar e o nascimento de filhotes prematuros. Entretanto, ao se considerar análises laboratoriais desses animais, pouquíssimos dados estão disponíveis quanto aos padrões hematológicos e bioquímicos, especialmente em caprinos prematuros, e tampouco se sabe sobre os efeitos da corticoterapia sobre parâmetros hematológicos e bioquímicos nesses animais. Nesse contexto, objetivou-se avaliar os parâmetros hematológicos e bioquímicos das primeiras horas de vida de cabritos prematuros provenientes de cabras que utilizaram diferentes protocolos de dexametasona. Para tal, as cabras foram divididas em três grupos: grupo I, cabras que receberam $20 \mathrm{mg}$ de dexametasona aos 139 dias de gestação; grupo II, 2 mg de dexametasona do 133 ${ }^{\circ}$ ao $136^{\circ}$ dia de gestação, $4 \mathrm{mg}$ do $137^{\circ}$ ao $139^{\circ}$ e $20 \mathrm{mg}$ no $140^{\circ}$ dia; grupo III, $16 \mathrm{mg}$ de dexametasona a partir do $139^{\circ}$ dia, com doses repetidas a cada 12 horas até a cirurgia eletiva; e grupo IV, cabras que receberam 4, 8, 16 e $20 \mathrm{mg}$ de dexametasona no $137^{\circ}, 138^{\circ}, 139^{\circ}$ e $140^{\circ}$ dias de gestação, respectivamente. As amostras sanguineas dos cabritos foram obtidas ao nascimento (T0h), 1 (T1h), 12 (T12h), 24 (T24h) e 48 horas (T48h) de vida para avaliação do hemograma e bioquímica sérica de ureia, creatinina, proteina total (PT) e gamaglutamiltransferase (GGT). Os teores de PT e atividade de GGT foram menores ao nascimento em todos os grupos, elevando-se após ingestão do colostro. Os valores de creatinina em todos os grupos experimentais não diferiram entre T0h e T1H, entretanto, diminuíram nos momentos subsequentes. Com exceção do grupo I, as concentrações de ureia foram maiores no T48h em comparação com o T1h. Os valores de hemácias, hemoglobina, hematócrito e volume corpuscular médio diminuíram ao longo do tempo, enquanto a concentração de hemoglobina corpuscular média aumentou ao longo do tempo. A contagem leucocitária total se comportou de maneira distinta nos diferentes grupos experimentais, demonstrado ser influenciada pelos teores de dexametasona principalmente em decorrência da alteração nas contagens de neutrófilos segmentados e linfócitos. Conclui-se que alterações significativas dos parâmetros hematológicos e bioquímicos ocorrem nas primeiras horas de vida de cabritos prematuros e o tratamento de cabras com dexametasona também pode afetar tais parâmetros de forma dependente da dose.

Palavras-chave: bioquímica, caprinos, corticoterapia, hematologia, parturição precoce. 


\section{INTRODUCTION}

In recent decades, to achieve fetal lung maturation, glucocorticoids have been applied to women 24 to $48 \mathrm{~h}$ before delivery. The maturation process of the fetal respiratory system begins during intrauterine life and extends into the postnatal period, under the influence of various endocrine factors (BOLT et al., 2001). One of these factors is the increased production of fetal cortisol at the end of pregnancy, which is involved in the regulation of lung, kidney, liver, and gastrointestinal development, and prepares newborns for postnatal life (FOWDEN \& FORHEAD, 1998).

A pioneering study on preterm lambs performed by LIGGINS \& HOWIE (1972) used synthetic corticosteroids during the prenatal period to artificially induce fetal lung maturation. This warranted other studies on ruminants, with the presentation of positive results for the techniques used (SCHMIDT et al., 2018). Dexamethasone, a synthetic glucocorticoid, is long-acting and has been widely recommended to reduce the occurrence of neonatal respiratory distress syndrome in preterm deliveries (CROWTHER et al., 2015).

Goats and sheep with multiple fetuses are often susceptible to metabolic disturbances in late pregnancy, such as pregnancy toxemia. The early decision to induce labor or cesarean delivery is extremely important, given the high lethality rate of such diseases (LIMA et al., 2016). However, these fetuses are not always fully mature, and hence, antenatal corticosteroid therapy has been studied to address this issue.

Dexamethasone proved to be efficient in reducing the mortality rate in premature lambs born at 138 days of gestation, by improving the clinical condition and survival of these animals (ÁVILA et al., 2014). This positive effect of the drug was also reported in goats, with no mortality in those premature animals from females that received antenatal therapy at 143 days of gestation (FEITOSA et al., 2020).

The importance of antenatal corticosteroid therapy in these cases is evident; however, hematological and biochemical alterations may occur. The white blood cell counts in lambs significantly decreased in the first $24 \mathrm{~h}$ under the influence of cumulative doses of dexamethasone (ZOLLER et al., 2015). It has also been reported that this drug lowers the hematocrit (Hct) levels of animals at 15 min of life. Premature lambs under the influence of dexamethasone had lower concentrations of total protein $(\mathrm{PT})$ compared with those that did not receive this therapy (FEITOSA et al., 2017). These alterations, despite being well discussed for lambs and calves, have not been investigated in goat species.

This study evaluated the hematological and biochemical parameters in the first $48 \mathrm{~h}$ of life of premature kids from goats subjected to different protocols of dexamethasone.

\section{MATERIALS AND METHODS}

Initially, to establish the prematurity protocol, the normal gestational times of three crossbred Boer goats raised under our management conditions were determined; they ranged from 151 to 155 days. Henceforth, the premature births in this research were performed approximately 11 days before the expected date for normal parturition, at 141 days of gestation.

Thirty-seven crossbred Boer kids from twenty-two goats subjected to different corticotherapy protocols (Dexacort $0.25 \%$, Marcolab Ind. Veterinary Products, Duque de Caxias, RJ, Brazil) were distributed into four experimental groups adopted from the literature (PUGH \& BAIRD, 2012; ZOLLER et al., 2015), as follows.

Group I: composed of ten kids born by cesarean delivery at 141 days of pregnancy, whose mothers received $20 \mathrm{mg}$ of dexamethasone in a single intramuscular application at 139 days of gestation, 2 days before surgery.

Group II: composed of nine kids born by cesarean delivery at 141 days of gestation, whose mothers received $2 \mathrm{mg}$ of dexamethasone intramuscularly from the 133rd to 136th day of gestation, $4 \mathrm{mg}$ from the 137 th to 139th day, and 20 $\mathrm{mg}$ on the 140th day of pregnancy.

Group III: composed of nine kids born by cesarean delivery at 141 days of gestation, whose mothers received $16 \mathrm{mg}$ of dexamethasone from 139 days of pregnancy, with repeated doses every $12 \mathrm{~h}$ until surgery.

Group IV: composed of nine kids born by cesarean delivery at 141 days of gestation, whose mothers received $4,8,16$, and $20 \mathrm{mg}$ of dexamethasone at 137, 138, 139, and 140 days of pregnancy, respectively.

The anesthetic procedure adopted in cesarean surgery employed local anesthesia with a proximal paravertebral block in the nerve sections of the T13, L1, and L2 vertebrae, using $5 \mathrm{~mL}$ of lidocaine hydrochloride (Xylestesin ${ }^{\circledR} \%$, Cristália, São Paulo, Brazil) for each dorsal and ventral point to the transverse processes. Lumbosacral epidural 
anesthesia was combined with morphine sulfate (Dimorf $^{\circledR}$, Cristália, Itapira, Brazil) at a dose of 0.1 $\mathrm{mg} / \mathrm{kg}$ diluted in $5 \mathrm{~mL}$ of saline solution. In cases where paravertebral anesthesia was not efficient, an infiltrative block was performed at the incision site with lidocaine hydrochloride. The surgical procedure was performed with the goats placed in the right lateral decubitus position, for an incision in the region of the left flank, according to the technique described by TIBARY \& VAN METRE (2004).

The newborns of the goats were fed colostrum from their mothers. If they did not voluntarily breastfeed within $2 \mathrm{~h}$ after birth, colostrum was supplied by bottles every $3 \mathrm{~h}$, at a volume corresponding to $10 \%$ of the live weight of the newborn. Animals that did not present a sucking reflex were fed with a nasogastric tube. The newborns that died during the study were subjected to necropsy to identify the cause of death.

Serial blood samples (approximately 5 $\mathrm{mL}$ ) were obtained by jugular puncture right after birth (T0h) and 1 (T1h), 12 (T12h), 24 (T24h), and $48 \mathrm{~h}$ (T48h) of life, and were placed in tubes with ethylenediaminetetraacetic acid (EDTA; BD Vacutainer $^{\circledR}$, Becton-Dickson, New Jersey, USA) to perform the blood count, and with coagulation activator (BD Vacutainer ${ }^{\circledR}$ ) to conduct serum analysis after centrifugation at $3000 \mathrm{rpm}$ for $10 \mathrm{~min}$. Serum samples were stored at $-20{ }^{\circ} \mathrm{C}$ until they were processed at the laboratory.

To perform the blood count, the counts of red blood cells, total leukocytes, and platelets, and the level of hemoglobin $(\mathrm{Hb})$, mean corpuscular volume (MCV), and mean corpuscular hemoglobin concentration (MCHC) were determined using a veterinary automated cell counter (BC-2800Vet, Shenzhen Mindray Bio-Medical Electronics Co., Nanshan, China). Hct levels were determined using the Strumia microcapillary method (11400 rpm for $5 \mathrm{~min}$ ), and the differential leukocyte count and morphological evaluation of red blood cells, leukocytes, and platelets were performed on a blood smear stained with commercial hematological dye (Instant-Prov, Newprov, Pinhais, PR, Brazil) under optical microscopy at $1000 \times$ magnification, following the recommendations of FELDMAN et al. (2000). The icteric index was determined using the potassium dichromate method, and the degree of icterus was recorded from 2 to 100 units (U) (FELDMAN et al., 2000).

Biochemical determinations were performed using a semi-automated photocolorimeter (SB-190 ${ }^{\circledR}$ Celm, Barueri, SP, Brazil) with a set of commercial reagents (Labtest Diagnóstica SA, Lagoa
Santa, MG, Brazil), following the manufacturer's recommendations. All the determinations were performed in duplicate at $37^{\circ} \mathrm{C}$ after calibration with a calibrator (Calibra H, Labtest Diagnóstica SA) and verification with level I (Qualitrol 1H, Labtest Diagnóstica SA) and II commercial controls (Qualitrol 2H, Labtest Diagnóstica SA). Creatinine, gammaglutamyltransferase (GGT), PT, and urea were determined using the alkaline picrate colorimetric method, modified Szasz method, biuret colorimetric method, and UV enzymatic method, respectively.

The variables were evaluated for normality and homogeneity of variances. Differences between time points were determined using analysis of variance with repeated measures and Tukey's post-hoc test, or the Friedman test with Dunn's post-hoc test. Comparisons between experimental groups were performed using the Kruskal-Wallis test with Dunn's post-hoc test. Statistical analyses were performed using a specific computer program (Statistical Analysis System, SAS, Version 9.0., Cary, NC, USA, 2002), and differences were considered significant at $\mathrm{P}<0.05$.

\section{RESULTS AND DISCUSSION}

Three out of ten goats in group I and three out of nine in group III died, all during the first $60 \mathrm{~min}$ of life. Of these, five died possibly due to respiratory failure (respiratory distress syndrome) and one in group II due to trauma (step by its mother and rib fractures, with perforation of the lungs).

The PT levels increased in all the experimental groups from $\mathrm{T} 24 \mathrm{~h}$ (Table 1), possibly due to the absorption of globulins present in the colostrum during the phase of greater intestinal permeability. Data from this research are similar to those of YANAKA et al. (2012), showing mean PT values of $3.76 \pm 0.40 \mathrm{~g} / \mathrm{dL}$ at birth, the lowest PT content before colostrum ingestion.

The measurement of serum PT can be used as an indirect method of evaluating $\mathrm{IgG}$, correlating with the total concentration of globulins. Hence, it has been used for the diagnosis of failed transfer of passive immunity (FTPI) in ruminants (CUTTANCE et al., 2019). There was no significant difference in the PT levels of the experimental groups, showing that the different dexamethasone protocols did not influence protein absorption by the kids. In addition, the highest values of PT observed at T24h and T48h in all the experimental groups were similar to those for goats born through normal delivery (BATMAZ et al., 2019), and were above the cutoff point of $5.4 \mathrm{~g} / \mathrm{dL}$ established by O'BRIEN \& SHERMAN (1993). This 
Table 1 - Total protein, creatinine and urea content (mean and standard deviation) of premature goats by caesarean at 141 days of intrauterine life, after administration of different protocols of dexamethasone in goats: group I ( $\mathrm{n}=10 \mathrm{newborns})-20 \mathrm{mg}$ dexamethasone at 139 days of gestation; group II ( $\mathrm{n}=9$ newborns) - $2 \mathrm{mg}$ of dexamethasone from the 133rd to the 136th day of gestation; $4 \mathrm{mg}$ from the $137 \mathrm{th}$ to the 139th day and $20 \mathrm{mg}$ on the 140th day of gestation; group III ( $\mathrm{n}=9 \mathrm{newborns})-16$ $\mathrm{mg}$ of dexamethasone every $12 \mathrm{~h}$ from 139 days of gestation until surgery; and group IV ( $\mathrm{n}=9$ newborns) - 4, 8, 16 and $20 \mathrm{mg}$ of dexamethasone at 137, 138, 139 and 140 days of gestation, respectively.

\begin{tabular}{|c|c|c|c|c|c|}
\hline \multirow[t]{2}{*}{ Variable } & \multirow[t]{2}{*}{ Moments (h) } & \multicolumn{4}{|c|}{ - } \\
\hline & & I & II & III & IV \\
\hline \multirow{5}{*}{ Total Protein $(g / d L)$} & $\mathrm{T}_{0}$ & $4.0 \pm 0.3 b$ & $3.9 \pm 0.5 \mathrm{c}$ & $3.6 \pm 0.4 \mathrm{c}$ & $3.9 \pm 0.4 b$ \\
\hline & $\mathrm{T}_{1}$ & $4.1 \pm 0.3 b$ & $4.1 \pm 0.4 \mathrm{c}$ & $3.6 \pm 0.6 \mathrm{c}$ & $4.0 \pm 0.7 b$ \\
\hline & $\mathrm{T}_{12}$ & $4.9 \pm 0.5 b$ & $4.9 \pm 0.7 b$ & $5.4 \pm 0.7 b$ & $5.3 \pm 1.4 \mathrm{a}$ \\
\hline & $\mathrm{T}_{24}$ & $6.4 \pm 1.1 \mathrm{a}$ & $5.7 \pm 0.9 \mathrm{a}$ & $5.8 \pm 0.7 \mathrm{ab}$ & $5.6 \pm 1.0 \mathrm{a}$ \\
\hline & $\mathrm{T}_{48}$ & $6.0 \pm 1.1 \mathrm{a}$ & $5.4 \pm 0.7 \mathrm{ab}$ & $6.1 \pm 0.8 \mathrm{a}$ & $5.3 \pm 0.9 \mathrm{a}$ \\
\hline \multirow{5}{*}{ Creatinine $(\mathrm{mg} / \mathrm{dL})$} & $\mathrm{T}_{0}$ & $1.84 \pm 0.18 \mathrm{a}$ & $1.62 \pm 0.18 \mathrm{a}$ & $1.69 \pm 0.32 \mathrm{a}$ & $1.73 \pm 0.50 \mathrm{a}$ \\
\hline & $\mathrm{T}_{1}$ & $1.75 \pm 0.16 \mathrm{a}$ & $1.54 \pm 0.28 \mathrm{a}$ & $1.59 \pm 0.32 \mathrm{a}$ & $1.65 \pm 0.50 \mathrm{a}$ \\
\hline & $\mathrm{T}_{12}$ & $1.37 \pm 0.30 \mathrm{~b}$ & $1.07 \pm 0.19 b$ & $1.00 \pm 0.09 \mathrm{~b}$ & $1.18 \pm 0.28 b$ \\
\hline & $\mathrm{T}_{24}$ & $0.86 \pm 0.24 \mathrm{c}$ & $0.86 \pm 0.20 \mathrm{c}$ & $0.79 \pm 0.06 \mathrm{c}$ & $0.79 \pm 0.06 \mathrm{c}$ \\
\hline & $\mathrm{T}_{48}$ & $0.70 \pm 0.14 \mathrm{c}$ & $0.70 \pm 0.12 \mathrm{c}$ & $0.73 \pm 0.06 \mathrm{c}$ & $0.71 \pm 0.09 \mathrm{c}$ \\
\hline \multirow{5}{*}{ Urea (mg/dL) } & $\mathrm{T}_{0}$ & $41.0 \pm 12.0$ & $32.0 \pm 12.0 \mathrm{~b}$ & $35.0 \pm 6.0 \mathrm{~b}$ & $31.0 \pm 6.0 \mathrm{ab}$ \\
\hline & $\mathrm{T}_{1}$ & $39.0 \pm 14.0$ & $29.0 \pm 8.0 \mathrm{~b}$ & $35.0 \pm 6.0 \mathrm{~b}$ & $29.0 \pm 3.0 \mathrm{~b}$ \\
\hline & $\mathrm{T}_{12}$ & $43.0 \pm 9.0 \mathrm{~A}$ & $36.0 \pm 8.0 \mathrm{ABb}$ & $28.0 \pm 5.0 \mathrm{Bb}$ & $29.0 \pm 7.0 \mathrm{Bb}$ \\
\hline & $\mathrm{T}_{24}$ & $51.0 \pm 15.0 \mathrm{~A}$ & $47.0 \pm 19.0 \mathrm{ABab}$ & $35.0 \pm 9.0 \mathrm{ABb}$ & $31.0 \pm 7.0 \mathrm{Bab}$ \\
\hline & $\mathrm{T}_{48}$ & $55.0 \pm 19.0$ & $56.0 \pm 20.0 \mathrm{a}$ & $49.0 \pm 15.0 \mathrm{a}$ & $42.0 \pm 15.0 \mathrm{a}$ \\
\hline
\end{tabular}

Means followed by different letters indicate a statistically significant difference $(\mathrm{P}<0.05)$ by the post-test. Uppercase letters highlight the differences between groups in columns and lowercase letters between moments in rows.

indicated that there was no FTPI and that prematurity and corticotherapy had no influence on this variable.

This finding is relevant since the inadequate transfer of passive immunity makes newborns sensitive to bacterial and viral infections (PERINO et al., 1995). In calves, prematurity may promote slower absorption of colostrum immunoglobulins. However, animals under the influence of corticosteroids may exhibit a higher absorption rate than those that are only immature, and even immunoglobulin concentrations do not reach the same levels as those reported in control group calves for up to 7 days; they can be considered satisfactory for immunological protection $12 \mathrm{~h}$ after birth (JOHNSTON \& STEWART, 1986).

Creatinine values for all the experimental groups did not differ between $\mathrm{T} 0 \mathrm{~h}$ and $\mathrm{T} 1 \mathrm{H}$; however, they decreased in the subsequent moments, coinciding with colostrum intake. In lambs born via vaginal delivery, the mean serum creatinine concentration before colostrum ingestion was $2.51 \mathrm{mg} / \mathrm{dL}$, which was four times higher than that obtained after colostrum ingestion (SOUZA et al., 2014). In this study, lower values were obtained at $\mathrm{T} 0$ and $\mathrm{T} 1 \mathrm{~h}$, and the reduction that occurred in the later moments was not of this magnitude. This reduction in creatinine levels as a function of time can be explained by the ingestion of fluids from the colostrum itself, which is essential for the maintenance of homeostasis, since the newborn is outside the uterus, in addition to the maturation of the urinary system (SOUZA et al., 2014), as reported for cattle (PICCIONE et al., 2010). Another phenomenon that may justify such a decrease is that, after birth, the kidneys assume their function (glomerular filtration), and this triggers a decrease in the serum creatinine supply of the neonate over time (SOUZA et al., 2014). When comparing experimental groups, there was no difference in this variable (Table 1), which also showed the lack of influence of different doses of corticosteroids on this marker of renal function in premature goats.

The urea levels were higher in groups II, III, and IV at T48h than at T1h, with no such difference being observed for group I (Table 1). With regard to the different dexamethasone treatments, it was possible to observe that group I exhibited higher urea levels at $\mathrm{T} 12 \mathrm{~h}$ compared with groups III and IV. This increase in urea concentration between the evaluated time points may have been related to the increase in the protein catabolism induced by cortisol that occurs in ruminants (SILANIKOVE, 2000) 
or by the increased protein metabolism due to the intake of colostrum proteins. However, it is likely that multiple doses of dexamethasone influence this dynamic, since there was no difference between the time points evaluated for group I. In premature lambs whose mothers received a single application of 16 mg of dexamethasone at 136 days of gestation, the concentrations of urea were lower at $\mathrm{T} 48 \mathrm{~h}$ than at the initial moments of life (FEITOSA et al., 2017). Variations in the renal biochemical profile of neonates may also be related to the immaturity of organic systems soon after birth, and despite the fluctuations found, the values obtained in this study are within the reference ranges for the species reported by BHAT et al. (2011) and MUNDIM et al. (2007).

Some enzymes such as FA (alkaline phosphatase) and GGT have been used to identify FTPI in newborn calves (FEITOSA et al., 2001). In this phase of life, the increase in serum activity of these enzymes may have not a hepatic origin, but rather a colostral one (THOMPSON \& PAULI, 1981). Therefore, due to its low cost and fast execution, the determination of serum GGT activity can be useful in the identification of goats with FTPI (SILVA et al., 2007). In the different groups with different corticotherapy protocols, an increase in GGT activity was observed from $\mathrm{T} 12 \mathrm{~h}$ (Table 2). The kids showed reduced enzyme activity in the first hour of life, with a subsequent increase at $\mathrm{T} 12 \mathrm{~h}$ and $\mathrm{T} 24 \mathrm{~h}$ in all the experimental groups. However, there was no difference regarding the various dexamethasone protocols, showing that the corticotherapy of the mothers with the different doses evaluated did not influence the intestinal absorption of GGT.
Normally, an elevation in GGT levels occurs after the ingestion of colostrum (YANAKA et al., 2012; BRAUN et al., 1978), a secretion that presents a high content of this enzyme, which in turn is absorbed by the intestinal mucosa. As FTPI is not detected in animals by PT assessment, the measurement of GGT for the diagnosis of FTPI in animals under the influence of corticotherapy should be done with caution. YANAKA et al. (2012) also determined the GGT activity in goats to detect FTPI; the GGT activity decreased soon after birth $(39.7 \pm$ $8.18 \mathrm{IU} / \mathrm{L})$ and increased after colostrum ingestion $(187.16 \pm 62.46 \mathrm{IU} / \mathrm{L})$. Similar results have also been observed for bovine species, and according to BRAUN et al. (1978), the GGT activity is $<28$ IU/L in newborn cattle before colostrum ingestion.

Based on the erythrogram, in general, there was a reduction in the levels of red blood cells, $\mathrm{Hb}$, and Hct in all the experimental groups over time after birth, with variations when this reduction was statistically significant in each experimental group (Table 3). FEITOSA et al. (2017), when evaluating the effect of prenatal dexamethasone in ewes, also observed a reduction in these erythrogram parameters after the birth of premature lambs. The higher erythrogram values at the initial moments may have been due to the incorporation of blood from the placenta into the circulation of the newborns. In addition, the stress caused by birth may also have raised the blood pressure and; consequently, caused good mobilization of red blood cells in the first moments after delivery. After birth, changes in body fluid dynamics also occur, leading to hemodilution in

Table 2 - Serum GGT activity (mean - M, minimum - Min and maximum - Max) of premature kids born by caesarean at 141 days of intrauterine life, after administration of different protocols of dexamethasone in goats: group I ( $\mathrm{n}=10$ goats) - $20 \mathrm{mg}$ of dexamethasone at 139 days of gestation; group II ( $\mathrm{n}=9$ goats) - $2 \mathrm{mg}$ of dexamethasone from the 133rd to the 136th day of gestation; $4 \mathrm{mg}$ from the 137 th to the 139 th day and $20 \mathrm{mg}$ on the 140th day of gestation; group III ( $\mathrm{n}=9$ goats) - $16 \mathrm{mg}$ of dexamethasone every $12 \mathrm{~h}$ from 139 days of gestation until surgery; and group IV ( $\mathrm{n}=9$ goats) - 4, 8, 16 and $20 \mathrm{mg}$ of dexamethasone at $137,138,139$ and 140 days of gestation, respectively.

\begin{tabular}{|c|c|c|c|c|c|c|c|c|c|}
\hline \multirow[t]{3}{*}{ Variable } & \multirow[t]{3}{*}{ Moments (h) } & \multicolumn{8}{|c|}{------------------------------------------------------------Groups------------------------------------------------------------- } \\
\hline & & \multicolumn{2}{|c|}{--------------I------------- } & \multicolumn{2}{|c|}{-------------II------------- } & \multicolumn{2}{|c|}{---------------III------------- } & \multicolumn{2}{|c|}{-------------IV----------- } \\
\hline & & M & Min-Max & M & Min-Max & M & Min-Max & M & Min-Max \\
\hline \multirow{5}{*}{$\begin{array}{l}\text { GGT } \\
(\mathrm{UI} / \mathrm{L})\end{array}$} & $\mathrm{T}_{0}$ & $31 \mathrm{~b}$ & $22-45$ & $32 \mathrm{~b}$ & 18-108 & $25 \mathrm{~b}$ & 19-31 & $28 \mathrm{~b}$ & 18-91 \\
\hline & $\mathrm{T}_{1}$ & $38 \mathrm{~b}$ & $21-144$ & $45 \mathrm{ab}$ & $24-438$ & $25 \mathrm{~b}$ & $16-272$ & $31 \mathrm{ab}$ & $19-772$ \\
\hline & $\mathrm{T}_{12}$ & $109 \mathrm{a}$ & $70-196$ & $191 \mathrm{a}$ & $43-483$ & $337 \mathrm{a}$ & $182-519$ & $129 \mathrm{a}$ & $65-715$ \\
\hline & $\mathrm{T}_{24}$ & $119 \mathrm{a}$ & $54-239$ & $177 \mathrm{a}$ & $37-376$ & $315 \mathrm{a}$ & $29-478$ & $144 \mathrm{a}$ & $61-718$ \\
\hline & $\mathrm{T}_{48}$ & $93 \mathrm{ab}$ & $57-103$ & $70 \mathrm{ab}$ & $20-216$ & $236 \mathrm{ab}$ & $32-288$ & $56 \mathrm{ab}$ & $23-250$ \\
\hline
\end{tabular}

Means followed by different letters indicate a statistically significant difference $(\mathrm{P}<0.05)$ by the post-test. Uppercase letters highlight the differences between groups in columns and lowercase letters between moments in rows.

Ciência Rural, v.52, n.6, 2022. 
Table 3 - Erythrogram values (mean and standard deviation), red blood cell concentration, hemoglobin content, hematocrit, mean corpuscular volume (MCV) and mean corpuscular hemoglobin concentration (MCHC) of premature kids born by caesarean at 141 days of life intrauterine, after administration of different protocols of dexamethasone in goats: group I ( $\mathrm{n}=10$ newborns) - $20 \mathrm{mg}$ of dexamethasone at 139 days of gestation; group II ( $\mathrm{n}=9$ newborns) - $2 \mathrm{mg}$ of dexamethasone from the $133 \mathrm{rd}$ to the 136th day of gestation; $4 \mathrm{mg}$ from the 137 th to the 139th day and $20 \mathrm{mg}$ on the 140th day of gestation; group III ( $\mathrm{n}=9$ newborns) - $16 \mathrm{mg}$ of dexamethasone every $12 \mathrm{~h}$ from 139 days of gestation until surgery; and group IV (n=9 newborns) $-4,8,16$ and $20 \mathrm{mg}$ of dexamethasone at 137, 138, 139 and 140 days of gestation, respectively.

\begin{tabular}{|c|c|c|c|c|c|}
\hline \multirow[t]{2}{*}{ Variable } & \multirow[t]{2}{*}{ Moments (h) } & \multicolumn{4}{|c|}{ 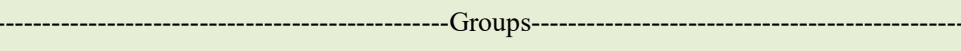 } \\
\hline & & I & II & III & IV \\
\hline \multirow{5}{*}{ Red blood cells $\left(\times 10^{12} / \mathrm{L}\right)$} & $\mathrm{T}_{0}$ & $7.7 \pm 0.79 \mathrm{a}$ & $7.62 \pm 1.77 \mathrm{a}$ & $8.0 \pm 1.7 \mathrm{a}$ & $7.53 \pm 1.62 \mathrm{a}$ \\
\hline & $\mathrm{T}_{1}$ & $7.4 \pm 1.21 \mathrm{ab}$ & $7.54 \pm 2.01 \mathrm{a}$ & $7.31 \pm 1.15 \mathrm{ab}$ & $7.11 \pm 1.81 \mathrm{ab}$ \\
\hline & $\mathrm{T}_{12}$ & $7.15 \pm 0.6 \mathrm{ab}$ & $7.56 \pm 2.01 \mathrm{a}$ & $6.25 \pm 0.70 \mathrm{bc}$ & $6.03 \pm 1.68 b$ \\
\hline & $\mathrm{T}_{24}$ & $6.49 \pm 0.67 \mathrm{~b}$ & $6.88 \pm 1.99 \mathrm{ab}$ & $5.54 \pm 0.99 \mathrm{c}$ & $6.03 \pm 1.43 \mathrm{~b}$ \\
\hline & $\mathrm{T}_{48}$ & $6.63 \pm 0.64 b$ & $6.18 \pm 0.82 b$ & $5.3 \pm 0.8 \mathrm{c}$ & $6.20 \pm 1.24 b$ \\
\hline \multirow{5}{*}{ Hemoglobin $(\mathrm{g} / \mathrm{dL})$} & $\mathrm{T}_{0}$ & $9.5 \pm 0.72 \mathrm{a}$ & $9.08 \pm 1.32 \mathrm{a}$ & $8.74 \pm 0.36 \mathrm{a}$ & $9.01 \pm 1.39 \mathrm{a}$ \\
\hline & $\mathrm{T}_{1}$ & $9.36 \pm 1.31 \mathrm{a}$ & $8.84 \pm 1.41 \mathrm{a}$ & $8.27 \pm 1.13 \mathrm{a}$ & $8.32 \pm 1.90 \mathrm{ab}$ \\
\hline & $\mathrm{T}_{12}$ & $9.0 \pm 1.11 \mathrm{a}$ & $8.37 \pm 1.51 \mathrm{ab}$ & $8.06 \pm 0.57 \mathrm{ab}$ & $6.98 \pm 1.97 \mathrm{~b}$ \\
\hline & $\mathrm{T}_{24}$ & $8.8 \pm 1.0 \mathrm{ab}$ & $7.85 \pm 1.19 b c$ & $7.21 \pm 1.14 b c$ & $7.35 \pm 1.75 b$ \\
\hline & $\mathrm{T}_{48}$ & $8.01 \pm 1.16 \mathrm{~b}$ & $7.25 \pm 1.30 \mathrm{c}$ & $6.88 \pm 0.71 \mathrm{c}$ & $7.24 \pm 1.14 b$ \\
\hline \multirow{5}{*}{ Hematocrit (\%) } & $\mathrm{T}_{0}$ & $35.6 \pm 2.7 \mathrm{a}$ & $33.9 \pm 5.7 \mathrm{a}$ & $33.3 \pm 2.3 \mathrm{a}$ & $34.6 \pm 5.3 \mathrm{a}$ \\
\hline & $\mathrm{T}_{1}$ & $34.1 \pm 3.1 \mathrm{a}$ & $33.3 \pm 5.8 \mathrm{a}$ & $30.2 \pm 1.7 \mathrm{~b}$ & $31.3 \pm 6.7 \mathrm{ab}$ \\
\hline & $\mathrm{T}_{12}$ & $31.4 \pm 4.2 \mathrm{~b}$ & $29.9 \pm 6.5 b$ & $28.0 \pm 2.0 \mathrm{~b}$ & $26.6 \pm 7.7 \mathrm{bc}$ \\
\hline & $\mathrm{T}_{24}$ & $29.1 \pm 3.7 \mathrm{~b}$ & $27.6 \pm 5.4 \mathrm{c}$ & $24.7 \pm 4.5 \mathrm{c}$ & $26.4 \pm 6.4 \mathrm{bc}$ \\
\hline & $\mathrm{T}_{48}$ & $25.9 \pm 3.2 \mathrm{c}$ & $24.7 \pm 5.2 \mathrm{~d}$ & $22.0 \pm 2.5 \mathrm{c}$ & $25.2 \pm 3.8 \mathrm{c}$ \\
\hline \multirow{5}{*}{ VCM (fL) } & $\mathrm{T}_{0}$ & $46.6 \pm 5.7 \mathrm{a}$ & $45.2 \pm 6.6 \mathrm{a}$ & $42.9 \pm 6.9$ & $46.6 \pm 7.2 \mathrm{a}$ \\
\hline & $\mathrm{T}_{1}$ & $45.1 \pm 8.0 \mathrm{a}$ & $45.2 \pm 6.6 \mathrm{a}$ & $41.9 \pm 5.2$ & $44.5 \pm 5.4 \mathrm{ab}$ \\
\hline & $\mathrm{T}_{12}$ & $44.0 \pm 5.6 \mathrm{ab}$ & $41.5 \pm 8.5 \mathrm{ab}$ & $45.0 \pm 3.3$ & $43.9 \pm 5.0 \mathrm{ab}$ \\
\hline & $\mathrm{T}_{24}$ & $45.2 \pm 7.3 \mathrm{ab}$ & $40.9 \pm 6.4 \mathrm{ab}$ & $44.7 \pm 4.6$ & $44.0 \pm 5.9 \mathrm{ab}$ \\
\hline & $\mathrm{T}_{48}$ & $38.9 \pm 3.3 \mathrm{~b}$ & $39.6 \pm 4.0 \mathrm{~b}$ & $41.7 \pm 2.9$ & $41.4 \pm 6.3 \mathrm{~b}$ \\
\hline \multirow{5}{*}{ CHCM (\%) } & $\mathrm{T}_{0}$ & $26.6 \pm 0.9 \mathrm{c}$ & $26.9 \pm 1.9 \mathrm{bc}$ & $26.3 \pm 1.7 \mathrm{c}$ & $26.0 \pm 0.6 \mathrm{~b}$ \\
\hline & $\mathrm{T}_{1}$ & $27.4 \pm 3.4 \mathrm{bc}$ & $26.5 \pm 1.2 \mathrm{c}$ & $27.4 \pm 3.8 \mathrm{bc}$ & $26.5 \pm 1.4 \mathrm{~b}$ \\
\hline & $\mathrm{T}_{12}$ & $28.6 \pm 1.4 \mathrm{abc}$ & $28.3 \pm 3.0 \mathrm{abc}$ & $28.8 \pm 1.8 \mathrm{abc}$ & $26.4 \pm 2.0 \mathrm{~b}$ \\
\hline & $\mathrm{T}_{24}$ & $30.2 \pm 1.8 \mathrm{ab}$ & $28.8 \pm 2.7 \mathrm{ab}$ & $29.3 \pm 0.9 \mathrm{ab}$ & $27.8 \pm 0.8 \mathrm{ab}$ \\
\hline & $\mathrm{T}_{48}$ & $30.9 \pm 1.4 \mathrm{a}$ & $29.6 \pm 2.5 \mathrm{a}$ & $31.3 \pm 2.0 \mathrm{a}$ & $28.7 \pm 1.2 \mathrm{a}$ \\
\hline
\end{tabular}

Means followed by different letters indicate a statistically significant difference $(\mathrm{P}<0.05)$ by the post-test. Uppercase letters highlight the differences between groups in columns and lowercase letters between moments in rows.

the postnatal moments, contributing to this reduction in red blood cell, $\mathrm{Hb}$, and Hct levels over time after birth (FELDMAN et al., 2000), and also increasing the absorption of liquids from colostrum ingestion. However, it is notable that even with this reduction, the values are within normal standards for adult animals according to BHAT et al. (2011). There was no significant difference between groups (Table 3), demonstrating that the duration of the protocol as well as the total dose of corticoids do not seem to influence all the erythrogram parameters.

MCV values also showed a significant reduction as a function of time for the experimental groups, except for group III (Table 3). A reduction in the size of red blood cells that occurs after birth may be due to the physiological changes induced by colostrum ingestion. Osmotically active substances absorbed from colostrum and present in the bloodstream attract water from the red blood cells themselves, reducing their volume, in addition to providing greater hemodilution, as evidenced by the reduction in the levels of red blood cells, $\mathrm{Hb}$, and Hct. In dogs, the reduction in postprandial MCV has already been demonstrated, corroborating this hypothesis (COSTA et al., 2020). Also consistent with this hypothesis, there was a gradual increase in $\mathrm{MCHC}$ over time in all the experimental groups (Table 3), indicating that the $\mathrm{Hb}$ concentration

Ciência Rural, v.52, n.6, 2022. 
increased within each red blood cell because of its volume loss, considering that mature red blood cells no longer exhibit hemoglobinization.

The results of white blood cell count differed based on the moment of obtaining the sample for different dexamethasone treatments. Group I showed an increase in total leukocyte count due to the increase in segmented neutrophil count at T12h, whereas group III showed only an increase in total leukocyte count at that time, without significant differences in the types of leukocytes. In group II; although there was no significant difference in the total leukocyte count, there was a significant increase in segmented neutrophil count at $\mathrm{T} 12 \mathrm{~h}$ and a reduction in lymphocyte count at T12h, T24h, and T48h. Group IV showed no significant change in total leukocyte and segmented neutrophil counts but showed a reduction in lymphocyte count at $\mathrm{T} 12 \mathrm{~h}$. There were no significant differences in monocyte and eosinophil counts with regard to the time points (Table 4). The counts of total leukocytes at birth were below those observed in adult animals (FELDMAN et al., 2000). The increase in total leukocyte counts at $\mathrm{T} 12 \mathrm{~h}$ in groups I and III demonstrated that in the shorter dexamethasone protocols, the leukocyte response required more time, as the count did not differ between time points for the other groups. Unlike what was observed in this study, the immunomodulatory effect of corticotherapy was observed in lambs under the influence of longer protocols, in which the leukocyte counts significantly decreased in the first $24 \mathrm{~h}$ of life (ZOLLER et al., 2015). The counts of

Table 4 - Leukogram (mean and standard deviation) with values of total leukocytes, segmented neutrophils, lymphocytes, monocytes and eosinophils of premature kids born by caesarean at 141 days of intrauterine life, after administration of different protocols of dexamethasone in goats: group I $(n=10)-20 \mathrm{mg}$ of dexamethasone at 139 days of gestation; group II ( $n=9)-2 \mathrm{mg}$ of dexamethasone from the 133rd to the 136th day of gestation; $4 \mathrm{mg}$ from the 137th to the 139th day and $20 \mathrm{mg}$ on the 140 th day of gestation; group III ( $\mathrm{n}=9$ ) - $16 \mathrm{mg}$ of dexamethasone every $12 \mathrm{~h}$ from 139 days of gestation until surgery; and group IV $(n=9)-4,8,16$ and $20 \mathrm{mg}$ of dexamethasone at 137, 138, 139 and 140 days of gestation, respectively.

\begin{tabular}{|c|c|c|c|c|c|}
\hline \multirow[t]{2}{*}{ Variable } & \multirow[t]{2}{*}{ Moments (h) } & \multicolumn{4}{|c|}{ 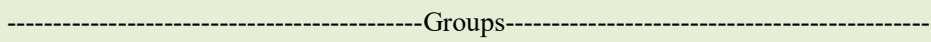 } \\
\hline & & I & II & III & IV \\
\hline \multirow{5}{*}{ Total leukocytes $\left(\times 10^{9} / \mathrm{L}\right)$} & $\mathrm{T}_{0}$ & $3.3 \pm 0.465 b$ & $3.6 \pm 0.685$ & $3.1 \pm 0.792 \mathrm{ab}$ & $3.7 \pm 0.663$ \\
\hline & $\mathrm{T}_{1}$ & $3.2 \pm 0.693 b$ & $3.4 \pm 0.546$ & $3.1 \pm 0.979 \mathrm{~b}$ & $3.1 \pm 0.653$ \\
\hline & $\mathrm{T}_{12}$ & $4.1 \pm 0.678 \mathrm{a}$ & $3.7 \pm 0.689$ & $4.2 \pm 0.331 \mathrm{a}$ & $3.1 \pm 0.832$ \\
\hline & $\mathrm{T}_{24}$ & $3.5 \pm 0.568 \mathrm{ab}$ & $3.5 \pm 0.609$ & $3.1 \pm 0.767 b$ & $3.1 \pm 0.864$ \\
\hline & $\mathrm{T}_{48}$ & $4.0 \pm 0.279 \mathrm{ab}$ & $3.6 \pm 0.575$ & $3.7 \pm 0.978 \mathrm{ab}$ & $3.4 \pm 0.757$ \\
\hline \multirow{5}{*}{ Segmented neutrophils $\left(\times 10^{6} / \mathrm{L}\right)$} & $\mathrm{T}_{0}$ & $1,107 \pm 470 \mathrm{c}$ & $934 \pm 416 b$ & $1,030 \pm 396$ & $1,321 \pm 663$ \\
\hline & $\mathrm{T}_{1}$ & $1,292 \pm 580 \mathrm{bc}$ & $1,116 \pm 446 b$ & $987 \pm 410$ & $1,133 \pm 292$ \\
\hline & $\mathrm{T}_{12}$ & $2,078 \pm 649 \mathrm{a}$ & $2,218 \pm 717 \mathrm{a}$ & $1,373 \pm 680$ & $1,402 \pm 554$ \\
\hline & $\mathrm{T}_{24}$ & $1,832 \pm 396 \mathrm{ABab}$ & $2,065 \pm 730 \mathrm{Aa}$ & $986 \pm 544 \mathrm{~B}$ & $1,360 \pm 601 \mathrm{AB}$ \\
\hline & $\mathrm{T}_{48}$ & $1,920 \pm 369 \mathrm{a}$ & $1,715 \pm 747 \mathrm{ab}$ & $1,461 \pm 449$ & $1,371 \pm 582$ \\
\hline \multirow{5}{*}{ Lymphocytes $\left(\times 10^{6} / \mathrm{L}\right)$} & $\mathrm{T}_{0}$ & $2,122 \pm 728 \mathrm{a}$ & $2,637 \pm 463 \mathrm{a}$ & $2,096 \pm 553$ & $2,372 \pm 594 \mathrm{a}$ \\
\hline & $\mathrm{T}_{1}$ & $1,985 \pm 621 \mathrm{a}$ & $2,216 \pm 499 \mathrm{ab}$ & $2,102 \pm 612$ & $1,916 \pm 699 \mathrm{ab}$ \\
\hline & $\mathrm{T}_{12}$ & $1,966 \pm 854 \mathrm{ABa}$ & $1,540 \pm 542 \mathrm{Bbc}$ & $2,797 \pm 600 \mathrm{~A}$ & $1,668 \pm 918 \mathrm{Bb}$ \\
\hline & $\mathrm{T}_{24}$ & $1,620 \pm 533 \mathrm{a}$ & $1,415 \pm 587 \mathrm{c}$ & $2,005 \pm 573$ & $1,741 \pm 773 \mathrm{ab}$ \\
\hline & $\mathrm{T}_{48}$ & $1,989 \pm 268 \mathrm{a}$ & $1,810 \pm 756 b c$ & $2,193 \pm 793$ & $2,055 \pm 767 \mathrm{ab}$ \\
\hline \multirow{5}{*}{ Monocytes $\left(\times 10^{6} / \mathrm{L}\right)$} & $\mathrm{T}_{0}$ & $27.1 \pm 29.01$ & $23.77 \pm 34.02$ & $3.33 \pm 10$ & $23.22 \pm 36.02$ \\
\hline & $\mathrm{T}_{1}$ & $19.5 \pm 20.43$ & $21.11 \pm 20.65$ & $15.77 \pm 19.22$ & $28 \pm 27.71$ \\
\hline & $\mathrm{T}_{12}$ & $27.57 \pm 34.43$ & $13.22 \pm 26.55$ & $6.16 \pm 15.10$ & $23 \pm 33.80$ \\
\hline & $\mathrm{T}_{24}$ & $19.57 \pm 25.48$ & $13.77 \pm 21.34$ & $27.5 \pm 31.99$ & $30.88 \pm 24.48$ \\
\hline & $\mathrm{T}_{48}$ & $88.57 \pm 60.65$ & $54.22 \pm 27.43$ & $21.2 \pm 33.27$ & $35.11 \pm 39.00$ \\
\hline \multirow{5}{*}{ Eosinophils $\left(\times 10^{6} / \mathrm{L}\right)$} & $\mathrm{T}_{0}$ & $3.5 \pm 10.5$ & 0 & $3.44 \pm 10.33$ & $4.22 \pm 12.66$ \\
\hline & $\mathrm{T}_{1}$ & $3.6 \pm 10.8$ & $2.66 \pm 7.54$ & 0 & $9.22 \pm 14.28$ \\
\hline & $\mathrm{T}_{12}$ & 0 & 0 & $7.33 \pm 17.96$ & $9.22 \pm 18.31$ \\
\hline & $\mathrm{T}_{24}$ & 0 & $4.22 \pm 11.94$ & 0 & $2.11 \pm 6.33$ \\
\hline & $\mathrm{T}_{48}$ & $16.57 \pm 28.29$ & 0 & $26 \pm 23.96$ & $20.22 \pm 26.66$ \\
\hline
\end{tabular}

Means followed by different letters indicate a statistically significant difference $(\mathrm{P}<0.05)$ by the post-test. Uppercase letters highlight the differences between groups in columns and lowercase letters between moments in rows.

Ciência Rural, v.52, n.6, 2022. 
segmented neutrophils and lymphocytes in newborns indicated that these two cell types remained similar but at different degrees, diverging from the pattern reported by BEZERRA et al. (2008).

In the experimental groups, there was no difference in the total leukocyte count, but group II had more segmented neutrophils than group III at T24h, whereas group III had higher lymphocyte counts than groups II and IV at T12h (Table 4). These results showed that corticotherapy performed on the mother affected the distribution of segmented neutrophils and lymphocytes in the first hours of life, with no significant differences being observed any longer on the second day of life. Corticosteroids can elevate the peripheral neutrophil count by accelerating their release from the marginal compartment and by reducing their clearance from the circulation (BISHOP et al., 1968). This stimulant effect has also been demonstrated in premature babies under the effect of antenatal betamethasone (BARAK et al., 1992). Thus, it could be shown that the duration of the corticotherapy protocol can interfere with the leukocyte response of newborn kids from premature births.

There was no significant difference in platelet contents and icteric index in all the experimental groups and for all the time points (Table 5); however, platelet counts were above the reference values for the species (FELDMAN et al., 2000). The use of corticoids can increase the platelet count via an effective increase in production, that is, the release of platelets from the bone marrow (GERNSHEIMER et al., 1989). As no differences were observed between the experimental groups, the duration of the protocols and the doses used most likely did not influence this parameter.

It was evident that the different protocols for treating goats with dexamethasone seemed to have a distinct influence on some hematological and biochemical parameters of preterm goats. However, one of the limitations of this study is the absence of a control group that would allow for evidence of the isolated changes induced by corticotherapy. It should be noted that inducing a premature birth at 141 days of gestation without inducing lung maturation might result in the death of most premature kids, which would not be approved by the Ethics Committee, making such a comparison impossible. Nevertheless, the values obtained in this study open new perspectives for understanding the hematological and biochemical alterations in premature goats, a species for which literature is lacking.

\section{CONCLUSION}

The hematological and biochemical parameters of premature goats undergo significant changes in the first hours of life; such data is lacking in the literature. These results can guide veterinarians regarding the diagnostic approach for such animals. In addition, dexamethasone corticotherapy for goats can change the hematological and biochemical

Table 5 - Platelet concentration and icteric index (mean and standard deviation) of premature kids born by cesarean section at 141 days of intrauterine life, after administration of different protocols of dexamethasone in goats: group I ( $\mathrm{n}=10$ goats) - $20 \mathrm{mg}$ of dexamethasone at 139 days of gestation; group II ( $\mathrm{n}=9$ goats) $-2 \mathrm{mg}$ of dexamethasone from the 133rd to the 136th day of gestation; $4 \mathrm{mg}$ from the 137 th to the 139 th day and $20 \mathrm{mg}$ on the 140th day of gestation; group III ( $\mathrm{n}=9 \mathrm{goats})-16 \mathrm{mg}$ of dexamethasone every $12 \mathrm{~h}$ from 139 days of gestation until surgery; and group IV ( $\mathrm{n}=9$ goats) - 4, 8, 16 and 20 mg of dexamethasone at 137, 138, 139 and 140 days of gestation, respectively.

\begin{tabular}{|c|c|c|c|c|c|}
\hline \multirow[t]{2}{*}{ Variable } & \multirow[t]{2}{*}{ Moments (h) } & \multicolumn{4}{|c|}{ 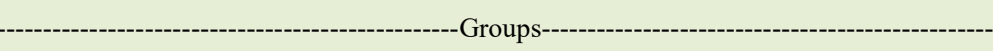 } \\
\hline & & I & II & III & IV \\
\hline \multirow{5}{*}{ Platelets $\left(\times 10^{9} / \mathrm{L}\right)$} & $\mathrm{T}_{0}$ & $634 \pm 165$ & $649 \pm 112$ & $578 \pm 82$ & $624 \pm 83$ \\
\hline & $\mathrm{T}_{1}$ & $594 \pm 148$ & $587 \pm 126$ & $593 \pm 131$ & $627 \pm 111$ \\
\hline & $\mathrm{T}_{12}$ & $631 \pm 161$ & $682 \pm 131$ & $567 \pm 162$ & $640 \pm 122$ \\
\hline & $\mathrm{T}_{24}$ & $620 \pm 122$ & $689 \pm 154$ & $597 \pm 121$ & $673 \pm 139$ \\
\hline & $\mathrm{T}_{48}$ & $663 \pm 207$ & $678 \pm 155$ & $604 \pm 97$ & $707 \pm 130$ \\
\hline \multirow{5}{*}{ Icteric índex (U) } & $\mathrm{T}_{0}$ & $3.5 \pm 1.58$ & $3.33 \pm 1.58$ & $2.33 \pm 1$ & $3.67 \pm 1.58$ \\
\hline & $\mathrm{T}_{1}$ & $3.5 \pm 1.58$ & $2 \pm 1.58$ & $2.33 \pm 1$ & $3.67 \pm 1.58$ \\
\hline & $\mathrm{T}_{12}$ & $3.87 \pm 1.55$ & $2 \pm 1.58$ & $2.5 \pm 1.22$ & $3.67 \pm 1.58$ \\
\hline & $\mathrm{T}_{24}$ & $3.87 \pm 1.55$ & $2 \pm 1.58$ & $2.5 \pm 1.22$ & $3.67 \pm 1.58$ \\
\hline & $\mathrm{T}_{48}$ & $3.71 \pm 1.60$ & $2 \pm 1.58$ & $2.6 \pm 1.34$ & $3.67 \pm 1.58$ \\
\hline
\end{tabular}

Means followed by different letters indicate a statistically significant difference $(\mathrm{P}<0.05)$ by the post-test. Uppercase letters highlight the differences between groups in columns and lowercase letters between moments in rows. 
parameters of premature goats in the first hours of life, depending on the variable and the dose used.

\section{ACKNOWLEDGEMENTS}

The T.R.T. was partial funded by the Brazilian Federal Agencies: "Coordenação de Aperfeiçoamento de Pessoal de Nível Superior" (CAPES), Brazil - Finance Code 001, and by the "Conselho Nacional de Desenvolvimento Científico e Tecnológico" (CNPq), Brazil. We would also like to thank the "Fundação de Amparo e Pesquisa do Estado de São Paulo" (FAPESP), for funding the research project no. 2013/22435-9, which this research is part of.

\section{DECLARATION OF CONFLICT OF} INTEREST

We have no conflict of interest to declare.

\section{AUTHORS' CONTRIBUTIONS}

All authors contributed equally for the conception and writing of the manuscript. All authors critically revised the manuscript and approved of the final version.

\section{BIOETHICS AND COMMITTEE APPROVAL}

BIOSECURITY

This study was submitted for evaluation to the Ethics Committee on the Use of Animals (CEUA) of the Faculty of Dentistry, UNESP/Araçatuba under Protocol 2016/00235.

\section{REFERENCES}

ÁVILA, L. G. et al. Maternal glucocorticoid in vital parameters of full-term and preterm lambs. Ciência Rural, v.44, n.6, p.11061112. 2014. Available from: <https://www.scielo.br/pdf/cr/v44n6/ a15414cr2013-0131.pdf>. Accessed: Aug. 15, 2020. doi: 10.1590/ S0103-84782014000600025.

BARAK, M. et al. Total leukocyte and neutrophil count changes associated with antenatal betamethasone administration in premature infants. Acta Paediatrica, v.81, p.760-763, 1992. Available from: <https:// onlinelibrary.wiley.com/doi/abs/10.1111/j.1651-2227.1992.tb12098.x>. Accessed: Aug. 15, 2020. doi: 10.1111/j.1651-2227.1992.tb12098.x.

BATMAZ, H. et al. Evaluation of passive transfer in goat kids with Brix refractometer and comparison with other semiquantitative tests. Turkish Journal of Veterinary and Animal Sciences, v.43, p.596-602, 2019. Available from: <https://journals.tubitak.gov.tr/ veterinary/issues/vet-19-43-5/vet-43-5-4-1905-31.pdf>. Accessed: Aug. 20, 2020. doi: 10.1111/j.1651-2227.1992.tb12098.x.

BEZERRA, L. R. et al. Perfil hematológico de cabras clinicamente sadias criadas no cariri paraibano. Ciência e Agrotecnologia, v.32, p.955-960, 2008. Available from: <https://www.scielo.br/ pdf/cagro/v32n3/a37v32n3.pdf >. Accessed: Aug. 15, 2020. doi: 10.1590/S1413-70542008000300037.

BHAT, S. A. et al. Hematological and biochemical parameters of Kashimiri goats in different climatic conditions.
International Journal for Agro Veterinary and Medical Sciences, v.5, p.481-487, 2011. Available from: <https://www. researchgate.net/publication/314092028_Hematological_and_ biochemicalparameters_of_Kashmiri_goats_in_different climatic conditions $>$. Accessed: Aug. 15, 2020. doi: $10.5455 /$ IJAVMS. 12944.

BISHOP, C. R. et al. Leukokinetic studies. XIII. A non-steady state kinetic evaluation of the mechanism of cortisone induced granulocytosis. The Journal Clinical Invest, v.47, p.249-260, 1968. Available from: <https://www.jci.org/articles/view/105721/ pdf $>$. Accessed: Aug. 15, 2020. doi: 10.1172/JCI105721.

BOLT, R. J. et al. Glucocorticoids and lung development in the fetus and preterm infant. Pediatric Pulmonolnary, v.32, p.7691, 2001. Available from: <https://onlinelibrary.wiley.com/doi/ epdf/10.1002/ppul.1092>. Accessed: Aug. 15, 2020. doi: 10.5455/ IJAVMS.12944.

BRAUN, J. P. et al. Tissue and blood distribuition of gammaglutamil transferase in the lamb and in the ewe. Research in Veterinary Science, v.25, p.25-37, 1978. Available from: <https://www. sciencedirect.com/science/article/abs/pii/S0034528818330054>. Accessed: Aug. 15, 2020. doi: 10.1016/S0034-5288(18)33005-4.

COSTA, L. et al. Diurnal variations in canine hematological parameters after commercial feed feeding. Semina-Ciencias Agrarias, v.41, p.2219 - 2230, 2020. Available from: <http://www.uel.br/revistas//uel/index.php/semagrarias/ article/view/38307/27800>. Accessed: Aug. 10, 2020. doi: 10.5433/1679-0359.2020v41n5Supl1p2219.

CROWTHER, C. A. et al. Repeat doses of prenatal corticosteroids for women at risk of preterm birth for improving neonatal health outcomes. Cochrane Database of Systematic Reviews, v.5, p.CD003935, 2015. Available from: <https://www.sciencedirect. com/science/article/abs/pii/S0034528818330054>. Accessed: Aug. 15, 2020. doi: 10.1002/14651858.CD003935.pub4.

CUTTANCE, E. L. et al. A review of diagnostic tests for diagnosing failure of transfer of passive immunity in dairy calves in New Zealand. New Zealand Veterinary Journal, v.67, n.6, p.277-286, 2019. Available from: <https://pubmed. ncbi.nlm.nih.gov/31401943/>. Accessed: Aug. 15, 2020. doi: 10.1080/00480169.2019.1654945.

FELDMAN, B. F. et al. Schalm's veterinary hematology. 5. ed. Baltimore: Lippincott Williams \& Wilkins, 2000.

FEITOSA, F. L. F. et al. DIAGNOSIS of passive immunity transfer failure in calves by total protein and its eletrophoretic fractions, immunoglobulins $\mathrm{G}$ and $\mathrm{M}$ quantification and gamma glutamyl transferase activity in serum. Ciência Rural, v.31, p.251-255, 2001. Available from: <https://www.scielo.br/pdf/cr/v31n2/ a10v31n2.pdf $>$. Accessed: Aug. 15, 2020.

FEITOSA, F. L. F. et al. Parâmetros hematológicos e perfil bioquímico renal de cordeiros nascidos a termo e prematuros. Arquivo Brasileiro de Medicina Veterinária e Zootecnia, v.69, p.627-636, 2017. Available from: <https:/www.scielo.br/pdf/ abmvz/v69n3/0102-0935-abmvz-69-03-00627.pdf $>$. Accessed: Aug. 15, 2020. doi: 10.1590/1678-4162-9098.

FEITOSA, F. L. F. et al. Hematologic parameters and renal biochemical profile in full-term and premature lambs. Arquivo Brasileiro de Medicina Veterinária e Zootecnia, v.72, n.4, 
p.1313-1320, 2020. Available from: <https:/www.scielo.br/pdf/ abmvz/v72n4/0102-0935-abmvz-72-04-1313.pdf>. Accessed: Aug. 15, 2020. doi: 10.1590/1678-4162-11522.

FOWDEN, A. L. et al. Glucocorticoids and the preparation for life after birth: are there long-term consequences of the life insurance? The Proceedings of the Nutrition Society, v.57, p.113-122, 1998. Available from: <https://pubmed.ncbi.nlm.nih.gov/9571716/>. Accessed: Aug. 15, 2020. doi: 10.1079/pns19980017.

GERNSHEIMER, T. et al. Mechanisms of response to treatment in autoimmune thrombocytopenic purpura. The New England Journal of Medicine, v.320, n. 15, p. 974-980, 1989. Available from: $<$ https://www.ncbi.nlm.nih.gov/pmc/articles/PMC5078877/> Accessed: Aug. 10, 2020. doi: 10.1056/NEJM198904133201505.

JOHNSTON, N. E.; STEWAR, J. A. The effect of glucocorticoids and prematurity on absorption of colostral immunoglobulin in the calf. Australian Veferinary Journal, v.63, n.6, p.191-192, 1986. Available from: <https://onlinelibrary.wiley.com/doi/ abs/10.1111/j.1751-0813.1986.tb02973.x>. Accessed: Dec. 15, 2020. doi: 10.1111/j.1751-0813.1986.tb02973.x.

LIGGINS, G. C.; HOWIE, R. N. A controlled trial of antepartum glucocorticoid treatment for prevention of the respiratory distress syndrome in premature infants. Pediatrics, v.50, p.515-525, 1972. Available from: <https://pediatrics.aappublications.org/ content/50/4/515.long >. Accessed: Aug. 15, 2020.

LIMA, M. S. et al. Usefulness of clinical observations and blood chemistry values for predicting clinical outcomes in dairy goats with pregnancy toxaemia. Irish Veterinary Journal, v.69, p.29, 2016. Available from: <https://www.ncbi.nlm.nih.gov/pmc articles/PMC5078877/>. Accessed: Aug. 15, 2020. doi: 10.1186/ s13620-016-0075-4.

MUNDIM, A. V. et al. Influence of parity and stage of lactation on the blood biochemical profile of Saanen goats. Arquivo Brasileiro de Medicina Veterinária e Zootecnia, v.59, p.306-312, 2007. Available from: <https://www.scielo.br/pdf/abmvz/v59n2/06.pdf >. Accessed: Aug. 15, 2020. doi: 10.1590/S0102-09352007000200006.

O'BRIEN, J. P.; SHERMAN, D. M. Field methods for estimating serum immunoglobulin concentrations in newborn kids. Small Ruminant Research, v.11, p.79-84, 1993. Available from: $\quad<\mathrm{https}$ :/www.sciencedirect.com/science/article/abs/ pii/0921448893901207>. Accessed: Aug. 15, 2020. doi: 10.1016/0921-4488(93)90120-7.

PERINO, L.J. et al. Effects of various risk factors on plasma protein and serum immunoglobulins concentra-tions of calves at postpartum hours 10 and 24. American Journal Veterinary Research, v.56, p.1144-1148, 1995. Available from: <https:// pubmed.ncbi.nlm.nih.gov/7486390/>. Accessed: Dec. 15, 2020.

PICCIONE, G. et al. Monitoring of physiological and blood parameters during perinatal and neonatal period in calves. Arquivo
Brasileiro de Medicina Veterinária e Zootecnia, v.62, p.1-12, 2010. Available from: <https://www.scielo.br/pdf/abmvz/v62n1/ v62n1a01.pdf>. Accessed: Aug. 15, 2020. doi: 10.1590/S010209352010000100001

PUGH, D. G.; BAIRD, A. N. Sheep and goat medicine. Missouri: Elsevier, 2012. 640p.

SCHMIDT, A. F. et al. Low-dose betamethasoneacetate for fetal lung maturation in preterm sheep. American Journal of Obstetrics \& Gynecology, v.218, p.132.e1-132.e9, 2018. Available from: <https://www.ajog.org/action/showPdf?pii $=\mathrm{S} 0002-9378 \% 2817 \% 2932325-6>$. Accessed: Aug. 15, 2020. doi: 10.1016/j.ajog.2017.11.560.

SILANIKOVE, N. Effects of heat stress on the welfare of extensively managed domestic ruminants. Livestock Production Science, v.67, p.1-18, 2000. Available from: <https://www. sciencedirect.com/science/article/abs/pii/S0301622600001627>. Accessed: Aug. 15, 2020. doi: 10.1016/S0301-6226(00)00162-7.

SILVA, S. L. et al. Evaluation of passive immunity in newborn goats feeding with goat and cow colostrum. Ars Veterinaria, v.23, p.81-88, 2007. Available from: <http://arsveterinaria.org.br/ars/ article/view/134/116>. Accessed: Aug. 15, 2020.

SOUZA, D. F. et al. Dinâmica pré e pós-colostral de parâmetros bioquímicos em cordeiros. Ciência Animal Brasileira, v.15, p.313-321, 2014. Available from: <https://www.scielo.br/pdf/cab/ v15n3/a10v15n3.pdf. Accessed: Aug. 15, 2020. doi: 10.1590/18096891v15i324807.

THOMPSON, J. C.; PAULI, J. V. Colostral transfer of gamma glutamyl transpeptidase in calves. New Zealand Veterinary Journal, v.29, p.223-226, 1981. Available from: <https:// www.tandfonline.com/doi/abs/10.1080/00480169.1981.34 851 ?journalCode $=\operatorname{tnzv20}>$. Accessed: Aug. 15, 2020. doi: $10.1080 / 00480169.1981 .34851$

TIBARY, A.; VAN METRE, D. Surgery of the sheep and goat reproductive system and urinary tract. In: FUBINI, S. L.; DUCHARME, N. G. Farm animal surgery. St. Louis: Saunders, 2004. p.527-547.

YANAKA, R. et al. Macromolecules intestinal absorption period of goat kids after bovine colostrum intake. Pesquisa Veterinária Brasileira v.32, p.794-802, 2012. Available from: <https://www.scielo. br/scielo.php?pid=S0100-736X2012000800020\&script $=$ sci abstract\&tlng=pt $>$. Accessed: Aug. 15, 2020. doi: 10.1590/S0100736X2012000800020.

ZOLLER, D. K. et al. Two treatment protocols for induction of preterm parturitionin ewes: evaluation of the effects on lung maturation and lamb survival. Small Ruminant Research, v.124, p.112-119, 2015. Available from: $<$ https://www.sciencedirect.com/ science/article/abs/pii/S0921448815000061>. Accessed: Aug. 15, 2020. doi: 10.1016/j.smallrumres.2014.12.015. 